\title{
AKTIVITAS ANTIOKSIDAN DAN ANTIBAKTERI EKSTRAK KULIT JERUK MANIS (Citrus sinensis) DAN APLIKASINYA SEBAGAI PENGAWET PANGAN
}

\author{
[Antioxidant and Antibacterial Activities of Sweet Orange (Citrus sinensis) Peels Extract \\ and Its Application as Food Preservative]
}

\author{
Ardhia Deasy Rosita Dewi* \\ Departemen Biologi, Fakultas Teknobiologi, Universitas Surabaya, Surabaya
}

Diterima 25 September 2017 / Disetujui 15 Maret 2019

\begin{abstract}
Microbial contamination may cause food poisoning and a decrease in food quality. Preservatives such as Citrus senensis sweet orange peel waste can be used to extend the shelf life of food. The purpose of this study was to measure the potential antioxidant and antibacterial activity of orange peel extract and its application to improve the quality of meatballs, wet noodles, and tofu. Meatballs, wet noodles, and tofu were soaked with the extract for 90 minutes prior to storage at room temperature $\left(28 \pm 2^{\circ} \mathrm{C}\right)$ for 4 days. The results showed that the inhibition zone of the extract using disc diffusion assay was $17.67 \pm 0.58 \mathrm{~mm}$ against Escherichia coli, $16 \pm 1 \mathrm{~mm}$ against Staphylococcus aureus, and $12.67 \pm 1.15 \mathrm{~mm}$ against Salmonella Typhi. Sweet orange peel extract had an antioxidant activity of $66.41 \%$ with total phenol of $2,656.48 \pm 55.46 \mathrm{mg}$ GAE/100g. The extract was able to reduce total bacteria between 0.5 and $1.0 \mathrm{log}$ CFU/g in meatballs, wet noodles and tofu. The application of the extract on meatballs, wet noodles and tofu preserved aroma and color attribute until $4^{\text {th }}$ day of storage at room temperature $\left(28 \pm 2^{\circ} \mathrm{C}\right)$. Decrease of texture attributes were observed starting from $3^{\text {rd }}$ day of storage at room temperature $\left(28 \pm 2^{\circ} \mathrm{C}\right)$.
\end{abstract}

Keywords: antibacterial activity, antioxidant activity, ethanolic extracts, food product, sweet orange peel

\section{ABSTRAK}

Kontaminasi mikroorganisme selain menyebabkan keracunan makanan, dapat menurunkan kualitas mutu bahan pangan. Hal tersebut membuat pengawet digunakan untuk memperpanjang umur simpan suatu bahan pangan seperti pemanfaatan limbah kulit jeruk manis (Citrus senensis).Tujuan penelitian ini adalah mengetahui potensi aktivitas antioksidan dan aktivitas antibakteri ekstrak kulit jeruk dan aplikasinya pada bahan pangan (bakso, mi basah, dan tahu). Bahan pangan direndam ekstrak selama 90 menit pada suhu ruang $\left(28 \pm 2^{\circ} \mathrm{C}\right)$ lalu disimpan selama 4 hari. Hasil penelitian menunjukkanzona penghambatan ekstrak menggunakan metode difusi agar sebesar 17,67 $\pm 0,58 \mathrm{~mm}$ terhadap Escherichia coli, $16 \pm 1 \mathrm{~mm}$ terhadap Staphylococcus aureus, dan $12,67 \pm 1,15 \mathrm{~mm}$ penghambatan terhadap bakteri Salmonella Typhi.

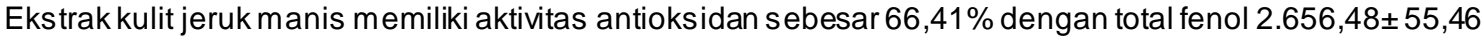
$\mathrm{mg}$ GAE/100g. Ekstrak bisa menurunkan total bakteri diantara 0,5 dan 1,0 Log CFU/g pada bakso, mi basah dan tahu. Aplikasi ekstrak dari tahu mi bakso melindungi aroma dan warna hingga penyimpanan hari ke 4 . Namun penurunan terjadi pada tekstur yang dimulai minggu ke pada suhu ruang $\left(28 \pm 2{ }^{\circ} \mathrm{C}\right)$.

Kata kunci: aktivitas antibakteri, aktivitas antioksidan, ekstrak etanol, kulit jeruk manis, produk pangan

\section{PENDAHULUAN}

Kontaminasi mikroorganisme selain menyebabkan keracunan makanan, dapat menurunkan kualitas mutu bahan pangan. Hal tersebut membuat pengawet marak digunakan untuk memperpanjang umur simpan suatu bahan pangan. Namun penggunaan pengawet non pangan seperti borak dan formalin masih menjadi prioritas bagi pelaku industri

*Penulis Korespondensi:

E-mail: deasyardhia@staff.ubaya.ac.id makanan rumah tangga. BPOM (2013) melaporkan di Surabaya ditemukan 3 sampel mi kuning, 10 sampel bakso dan 15 sampel tahu positif mengandung pengawet non pangan. Makanan yang menggunakan pengawet non pangan pada umumnya adalah makanan dengan umur simpan pendek sekitar 2436 jam pada suhu ruang. Pengawet berbahaya dipilih karena harganya yang murah dan penggunaannya dapat menjaga kualitas bahan (warna dan tekstur) lebih lama.

Permasalahan yang terjadi seputar pengawet non pangan yang masih digunakan memunculkan 
pengawet pangan yang termasuk bahan tambahan pangan. Namun, penambahan yang tidak sesuai acceptable daily intake (ADI) akan menimbulkan efek buruk bagi kesehatan. Berdasarkan kenyataan tersebut, tren bahan tambahan pangan alami mulai banyak diteliti, khususnya senyawa alam yang memiliki efek mengawetkan bahan pangan. Menurut Widiastuti (2016), senyawa alkaloid, kuinon, dan terpenoid dalam temulawak mampu menghambat aktivitas bakteri Staphylococcus aureus, Streptcoccus, dan Bacillus pada daging ayam dan ikan. Tohyeng et al. (2018) juga menambahkan, kurkuminoid dalam ekstrak kunyit dapat mengendalikan pertumbuhan bakteri pathogen seperti Escherichia coli dan Salmonella pada penyimpanan tahu selama 72 jam di suhu ruang. Berdasarkan sifat antibakteri senyawa alam, limbah kulit jeruk manis berpotensi untuk dijadikan pengawet alami karena mampu menghambat beberapa mikroorganisme pembusuk dan patogen (Mehmood et al., 2015; Favela-Hernández et al., 2016). Ketersediaan limbah kulit jeruk manis juga melimpah dengan total produktivitas mencapai 309.678 ton tiap tahunnya (Kementrian Pertanian, 2010).

Limbah kulit jeruk manis yang diekstraksi menggunakan pelarut organik (petroleum eter, hexane, etanol, eter) menghasilkan ekstrak yang memiliki aktivitas yang mampu menghambat E.coli, S.aureus, Saccharomyces cerevisiae, Aspergillus niger (Liu et al., 2012), Salmonella (O'Bryan et al., 2008), Klebsiella pneumonia, Shigella flexneri, Enterobacter amnigenus (Mehmood et al., 2015) Candida albicans (Mehmood et al., 2015) dan Mycobacterium tubercolosis H37RV serta Penicillium digitatum dan Cladosporium cucumerinum (Favela-Hernández et al., 2016). Mehmood et al. (2015) juga melaporkan, ekstrak kulit jeruk manis memiliki aktivitas antioksidan sebesar 70,2\% menggunakan metode DPPH (2,2-Diphenyl-1-picrylhydrazyl) dan mengandung beberapa senyawa seperti C-glycosylated flavones, Oglycosylated flavones, polymethoxylated flavones, O-glycosylated flavanones.

Berdasarkan potensi ekstrak kulit jeruk manis sebagai antibakteri dan antioksidan, ekstrak ini berpeluang untuk digunakan sebagai pengawet alami untuk bahan makanan khususnya bahan makanan yang sering dikonsumsi masyrakat. Menurut Arisanti et al. (2018), bahan baku masakan yang sering digunakan adalah mi kuning, tahu, dan bakso, dimana bahan baku tersebut adalah bahan yang mengandung protein dan berkadar air tinggi serta dipasarkan pada suhu ruang. Sumber nitrogen dan air adalah nutrisi yang dibutuhkan oleh banyak mikroorganisme untuk menunjang kehidupannya pada suatu substrat tertentu. Satyajaya (2008) menambahkan total mikroba dalam mi basah mencapai lebih dari sepuluh juta per gram. Standar mikroba pada mi ba- sah seharusnya satu juta mikroba per gram (SNI 7388:2009).

Tujuan penelitian ini adalah melakukan karakterisasi ekstrak kulit jeruk manis dan melihat aplikasinya pada produkpangan (bakso, mi basah, dan tahu) yang direndam ekstrak selama penyimpanan pada suhu ruang terhadap total mikroba dan karakteristik visual bahan pangan.

\section{BAHAN DAN METODE}

\section{Bahan}

Bahan yang digunakan dalam pembuatan ekstrak kulit jeruk manis (Gambar 1) adalah kulit jeruk manis (Citrus senensis) dengan tingkat kematangan buah $80 \%$ (tekstur kulit halus, tipis, mengkilat dan warna yang tegas). Limbah kulit jeruk diperoleh dari pedagang minuman jeruk manis di Kota Malang Provinsi Jawa Timur. Produk olahan pangan seperti bakso dibeli dari pedagang bakso terkenal di Kota Surabaya, sedangkan mi basah dan tahu putih diperoleh dari pabrik mi dan tahu di Kota Surabaya.

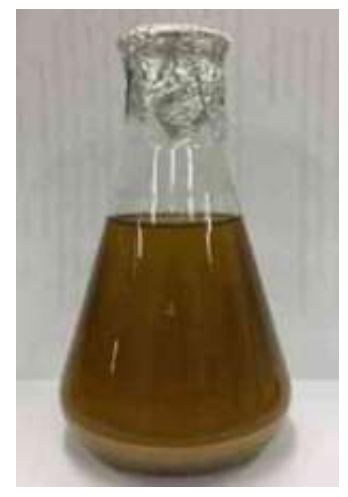

Gambar 1. Ekstrak kulit jeruk manis

\section{Pembuatan ekstrak kulit jeruk}

Metode ekstraksi kulit jeruk mengikuti metode yang dilakukan oleh Mehmood et al. (2015) yaitu kulit jeruk diiris tipis dan dikeringkan pada suhu $60^{\circ} \mathrm{C}$ menggunakan cabinet dryer selama 24 jam. Kulit jeruk yang sudah kering dihaluskan dengan menggunakan grinder (Philips HL 7720, Japan) kemudian disaring dengan ayakan 70 mesh.

Ekstrak kulit jeruk didapatkan dengan metode maserasi. Sebanyak 30 gram bubuk kulit jeruk direndam dalam 300mL etanol (Merck®, Germany) anhydrous sdengan perbandingan 1:10, dilanjutkan dengan agitasi $500 \mathrm{rpm}$ pada suhu ruang $\left(28 \pm 2^{\circ} \mathrm{C}\right)$ selama 2 jam. Kemudian, agitasi dihentikan dan maserasi dilakukan hingga mencapai 24 jam. Ekstrak yang didapat disaring dengan kertas saring lalu eluen diuapkan dengan rotary evaporator (Buchi R20, Sigma Aldrich, Germany) dengan pengaturan rotasi $60 \mathrm{rpm}$, suhu $50^{\circ} \mathrm{C}$, dan tekanan $100 \mathrm{mbar}$ sela- 
ma 2 jam. Penguapan dihentikan ketika didapatkan ekstrak kulit jerukyang pekat (berwarna kuning kehijauan. Sebelum diaplikasikan ke bahan pangan, ekstrak kulit jeruk lebih dulu dilarutkan ke dalam akuades dengan konsentrasi $1 \%$ (b/v) dan dipanaskan pada suhu $70^{\circ} \mathrm{C}$ selama 30 menit.

\section{Rendemen ekstrak}

Ekstrak kulit jeruk manis hasil evaporasi memiliki warna kuning kehijauan dan tidak berbau etanol. Rendemen ekstrak dihitung menurut rumus sebagai berikut:

$$
\% \text { Rendemen }=\frac{\text { Berat ekstrak }(g)}{\text { Berat bubuk kulit jeruk }(g)} \times 100 \%
$$

\section{Analisis kandungan senyawa fenolik mengguna- kan reagen Folin-Ciocalteau}

Analisis kandungan senyawa fenolik dalam ekstrak kulit jeruk manis dilakukan dengan metode total phenolic compound (TPC). Sebanyak $200 \mu \mathrm{L}$ ekstrak kulit jeruk dicampurkan dengan $2,5 \mathrm{~mL}$ reagen Folin-Ciocalteau 10\% (Merck Milipore, Germany) dan $2 \mathrm{~mL}$ larutan $\mathrm{Na}_{2} \mathrm{CO}_{3} 7,5 \%$ kemudian dihomogenkan. Campuran larutan diinkubasi pada suhu $45^{\circ} \mathrm{C}$ selama 15 menit kemudian serapan larutan diukur dengan menggunakan spektrofotometer (Thermo fisher scientific, Indonesia) pada panjang gelombang $765 \mathrm{~nm}$. Blanko dipersiapkan dengan mengganti ekstrak kulit jeruk dengan akuades. Hasil serapan yang didapatkan kemudian dibandingkan dengan kurva standard senyawa fenolik total. (Agbor et al., 2014)

\section{Analisis aktivitas antioksidan}

Analisis aktivitas antioksidan ekstrak kulit jeruk dilakukan dengan menggunakan reagen DPPH (2,2diphenyl-1-picrylhydrazyl) (Merck Milipore, Germany). Sebanyak $200 \mu \mathrm{L}$ ekstrak kulit jeruk dicampurkan dengan $200 \mu \mathrm{L}$ reagen DPPH kemudian dihomogenkan. Campuran larutan diinkubasi pada ruang gelap selama 30 menit kemudian serapan larutan diukur dengan menggunakan spektrofotometer pada panjang gelombang $517 \mathrm{~nm}$. Blanko yang digunakan berisikan DPPH sedangkan rasio perbandingan sampel dan DPPH adalah 1:1. Hasil serapan yang didapatkan kemudian dikonversi menjadi persentase inhibisi menggunakan rumus sebagai berikut (Prakash et al., 2010):

$$
\% \text { Inhibisi }=\frac{\text { Absorbansi kontrol-Absorbansi sampel }}{\text { Absorbansi kontrol }} \times 100 \%
$$

\section{Pengujian aktivitas antimikroba ekstrak kulit jeruk dengan metode difusi agar}

Pengujian aktivitas antimikroba ekstrak kulit jeruk dilakukan dengan menggunakan cylindercup mengikuti metode Mulyono et al. (2013). Kultur Es- cherichia coli, Staphylococcus aureus, dan Salmonella typhii ditumbuhkan dalam media nutrient broth (Merck®, Germany) dan diinkubasi pada $37^{\circ} \mathrm{C}$ selama 24 jam dengan agitasi 150 rpm hingga mencapai $\mathrm{OD}_{600}=0,5$ (Waterbath, orbital shaker, Thermo fisher scientific, Indonesia) sebanyak $100 \mu \mathrm{L}$ kultur cair dimasukkan ke dalam cawan petri steril secara aseptis, kemudian ditambahkan $15 \mathrm{~mL}$ media nutrient agar (Merck®, Germany) steril dan dihomogenkan. Setelah media memadat, cylinder cup steril dimasukkan pada permukaan media.

Sebanyak $100 \mu \mathrm{L}$ kontrol positif dan negatif dimasukkan ke dalam cylinder cup. Kontrol positif yang digunakan adalah antibiotik ampicilin (100 $\mathrm{mg} / \mathrm{mL}$ ) dan kloramfenikol $(5 \mathrm{mg} / \mathrm{mL}$ ) (Sigma Aldrich, Germany). Kontrol negatif yang digunakan adalah etanol hasil evaporasi ektrak encer kulit jeruk. Cawan petri berisi cylinder cup kemudian diinkubasi pada suhu $37^{\circ} \mathrm{C}$ selama 16 jam kemudian diamati adanya zona bening dan diukur diameter hambatnya.

\section{Aplikasi ekstrak kulit jeruk pada bahan pangan}

Sebelum diaplikasikan pada produk olahan pangan (bakso, mi, dan tahu), ekstrak kulit jeruk manis terlebih dahulu diencerkan menggunakan akuades steril hinga konsentrasi ekstrak $500 \mathrm{mg} / \mathrm{ml}$. Pengujian ekstrak kulit jeruk dilakukan dengan cara perendaman bahan pangan menggunakan ekstrak mengikuti metode Tohyeng (2018). Perbandingan ekstrak dengan bahan pangan yaitu $1: 1$. Bahan pangan yang telah direndam $(0,30,60,90$ menit) kemudian dipindahkan ke dalam cawan petri steril dan diinkubasi pada suhu ruang $\left(26-29^{\circ} \mathrm{C}\right)$ selama masa penyimpanan $0,1,2,3,4$ hari. Setiap hari dilakukan analisis total mikroba menggunakan metode total plate count (TPC). Desain penelitian dapat diihat pada Tabel 1.

\section{Pengamatan bahan pangan yang telah direndam ekstrak kulit jeruk manis}

Bahan pangan ditimbang $10 \mathrm{~g}$ lalu dilakukan perendaman dengan ekstrak kulit jeruk manis selama $(0,30,60,90$ menit dan diinkubasi pada suhu ruang $\left(26-29^{\circ} \mathrm{C}\right)$ selama masa penyimpanan $0,1,2,3,4$ hari. Pengamatan dilakukan dengan memberikan keterangan karakteristik bahan pangan mulai dari normal (aroma, warna, dan tekstur masih sama dengan produk kontrol) hingga sangat rusak (aroma busuk dan tengik, warna kuning kecoklatan, dan tekstur rapuh/lembek) pada atribut warna, aroma, dan tekstur.

\section{Analisis data}

Penelitian ini menggunakan rancangan acak lengkap faktorial (RALF) $4 \times 4$ dengan lama perendaman bahan pangan (4 level) terhadap waktu penyimpanan (4 level). Data hasil penelitian diolah 
menggunakan software SPSS IBM 22. Perbedaan perlakuan dianalisis dengan uji ANOVA dan jika berbeda signifikan maka dilanjutkan dengan uji post hoc Tukey dengan taraf nyata $5 \%$.

Tabel 1. Desain penelitian aktivitas antioksidan dan antibakteri ekstrak kulit jeruk manis dan aplikasinya sebagai pengawet pangan

\begin{tabular}{|c|c|}
\hline Perlakuan & Pengujian \\
\hline $\begin{array}{l}\text { Karakterisasi } \\
\text { ekstrak kulit jeruk } \\
\text { manis }\end{array}$ & $\begin{array}{l}\text { 1. Rendemen ekstrak kulit jeruk } \\
\text { manis } \\
\text { 2. Aktivitas antioksidan } \\
\text { 3. Total senyawa fenolik } \\
\text { 4. Aktivitas antibakteri }\end{array}$ \\
\hline $\begin{array}{l}\text { Aplikasi ekstrak } \\
\text { kulit jeruk manis } \\
\text { pada bahan } \\
\text { pangan }\end{array}$ & $\begin{array}{l}\text { 1. Pengujian borak dan formalin } \\
\text { pada bahan pangan (bakso, } \\
\text { mi, dan tahu) } \\
\text { 2. Total Mikroba bahan pangan } \\
\text { setelah direndam ekstrak se- } \\
\text { lama } 0,30,60,90 \text { menit dengan } \\
\text { lama penyimpanan selama } 0 \text {, } \\
1,2,3,4 \text { hari } \\
\text { 3. Pengamatan visual bahan pa- } \\
\text { ngan dan air rendamannya } \\
\text { saat penyimpanan } 0,1,2,3,4 \\
\text { hari }\end{array}$ \\
\hline
\end{tabular}

\section{HASIL DAN PEMBAHASAN}

\section{Rendemen ekstrak kulit jeruk}

Rendemen ekstrak kulit jeruk berwarna kuning kehijauan dan tidak berbau etanoldengan rendemen sebesar $25 \%$. Rendemen dihitung terhadap berat bubuk kulit jeruk kering dengan kadar air $12 \% \mathrm{~b} / \mathrm{b}$. Komponen fenolik yang terekstrak dalam ekstrak kulit jeruk manis berkisar dari semipolar sampai polar. Bagian komponen polar akan terekstrak dengan etanol yang mempunyai konstanta dielektrik 24,30 (Sax dan Lewis, 1998). Hal tersebut sesuai dengan penelitian Rafsanjani (2015), hasil ekstrak kulit jeruk dengan pelarut etanol menunjukkan total fenol paling tinggi dibanding pelarut air dan etil asetat. Metode ekstraksi dengan maserasi merupakan metode yang mudah dilakukan dan menghasilkan rendemen yang relatif tinggi (Tohyeng, 2018).

\section{Aktivitas antibakteri}

Pengujian ekstrak kulit jeruk terhadap beberapa bakteri (Escherichia coli, Staphylococcus aureus, dan Salmonella typhi) menunjukkan adanya zona bening di sekitar disk. Komponen antimikroba pada kulit jeruk manis adalah minyak atsiri yang disusun oleh komponen decanal $(73,36 \%)$, octanal $(78,12 \%)$ dan linalool $(90,61 \%)$ dengan mampu menghambat beberapa mikroorganisme seperti E.coli, S.aureus, Saccharomuyces cerevisiae, Aspergillus niger (Kaviya et al., 2011; Liu et al., 2012). Hal itu sesuai dengan data diameter zona bening tertinggi yang ditunjukkan Tabel 2, yaitu ekstrak kulit jeruk manis pa- da Escherichia coli sebesar 17,67 $\pm 0,58 \mathrm{~mm}$ diikuti oleh Staphylococcus aureus, dan Salmonella typhi masing-masing sebesar $16,00 \pm 1$ dan $12,67 \pm 1,15$ $\mathrm{mm}$.

Tabel 2. Diameter zona bening ekstrak kulit jeruk manis

\begin{tabular}{lccc}
\hline \multirow{2}{*}{ Bakteri } & \multicolumn{3}{c}{ Diameter Zona Bening $(\mathrm{mm})$} \\
\cline { 2 - 4 } & Kontrol & Kontrol & Sampel \\
& Positif & Negatif & \\
\hline Escherichia coli & $21,33 \pm$ & $10,00 \pm$ & $17,67 \pm$ \\
& 0,58 & 1,00 & 0,58 \\
Staphylococcus & $41,33 \pm$ & $9,33 \pm$ & $16,00 \pm$ \\
aureus & 1,15 & 0,58 & 1,00 \\
Salmonella typhi & $22,67 \pm$ & $10,33 \pm$ & $12,67 \pm$ \\
& 1,15 & 0,58 & 1,15 \\
\hline
\end{tabular}

\section{Kandungan senyawa fenolik dan aktivitas antiok- sidan}

Kandungan senyawa fenolik total dan aktivitas antioksidan diuji menggunakan ekstrak kulit jeruk dengan konsentrasi $10 \mathrm{mg} / \mathrm{mL}$ dan didapatkan total phenolic content sebesar 2,656 $\pm 55,46 \mathrm{mg}$ GAE/ $100 \mathrm{~g}$ dan aktivitas antioksidan yang dinyatakan dengan \% inhibisi DPPH sebesar $66,41 \pm 1,68 \%$ ditunjukkan pada Tabel 3 . Total senyawa fenolik pada kulit jeruk berkisar 0,67-7,30 $\mathrm{g} / 100 \mathrm{~g}$ berat kering (Boudhrioua et al., 2016). Pemilihan metode ekstraksi menggunakan etanol, akan meningkatkan komponen fenolik yang terekstrak yang berperan sebagai senyawa antioksidan. Hal ini sesuai dengan penelitian Boudhrioua et al. (2016) bahwa ekstraksi kulit jeruk menggunakan pelarut etanol secara konvensional menghasilkan aktivitas antioksidan yang lebih besar dibanding kulit jeruk yang diekstraksi menggunakan pelarut etanol melalui gelombang mikro.

Tabel 3. Kandungan senyawa fenolik total dan aktivitas antioksidan ekstrak kulit jeruk manis

\begin{tabular}{cc}
$\begin{array}{c}\text { Total Phenolic Compound (mg } \\
\text { GAE } / 100 \text { g ekstrak) }\end{array}$ & $\begin{array}{c}\text { Aktivitas Antioksidan } \\
(\%)\end{array}$ \\
\hline $2.656,48 \pm 55,46$ & $66,41 \pm 1,68$ \\
\hline
\end{tabular}

Neohesperidin, hesperidin, 5-C-glycosyl flavornes: lucenin-2, vicenin-2, stellarin-2, lucenin-2-41methyl ether and scoparin; one 3-hydroxy-3-methylglutaryl glycosylflavonol: 3-hydroxy-3-methylglutaryl glycosyl quercetin; and one flavone O-glycosides: chrysoeriol7-O-neoesperidoside dan komponen fenolik yaitu polymethoxylated flavones, O-glycosylated flavones, C-glycosylated flavones, O-glycosylated flavonols, O-glycosylated flavanones (glycosylated flavonones) adalah golongan fenolik yang memiliki aktivitas antioksidan pada kulit jeruk manis (Barreca et al., 2014; Boudhrioua et al., 2016). 


\section{Aplikasi pada bahan pangan}

Semakin lama perendaman, jumlah bakteri makin menurun. Perendaman selama 90 menit memberikan hasil terbaik dengan total mikroba terkecil hingga hari ke-4. Hal ini dikarenakan aktivitas antibakteri yang dimiliki ekstrak kulit jeruk mampu menghambat beberapa strain bakteri dan jamur. Kaviya et al. (2011) menjelaskan, aktivitas antibakteri dari minyak atsiri dan ekstrak kasar dari kulit jeruk Citrus senensis yang diekstrak dengan air secara maserasi menunjukkan mampu menghambat Escherichia coli, Pseudomonas aeruginosa, dan Staphylococcus aureus.

Pada penelitian ini, ekstrak kulit jeruk manis dengan konsentrasi $500 \mathrm{mg} / \mathrm{ml}$ dan lama perendaman 90 menit mampu mempertahankan bakso daging selama 4 hari pada suhu ruang. Pada Gambar 2, menunjukkan bahwa semakin lama perendaman, total bakteri makin menurun. Perendaman selama 90 menit memberikan hasil terbaik dengan total mikroba terkecil mi hingga hari ke-4 dibandingkan dengan kontrol yang ditunjukkan pada Gambar 3. Hal ini dikarenakan senyawa antibakteri yang dimiliki ekstrak kulit jeruk mampu menghambat beberapa strain bakteri dan jamur. Ekstraksi Kulit jeruk manis banyak menghasilkan minyak atsiri yang kaya akan karotenoid, senyawa fenolik, tokoferol dan fitosterol (Jorge et al., 2016). Menurut Suryanti et al. (2011) senyawa fenol mempunyai hambatan dalam pembentukan dinding sel, sedangkan flavonoid juga dapat merusak dinding sel, dan senyawa terpenoid mampu merusak membran bakteri.

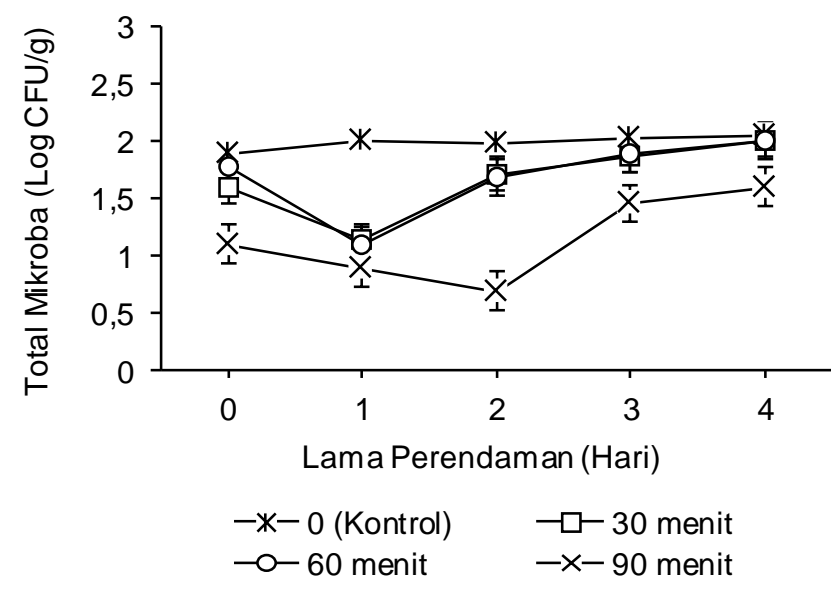

Keterangan: Kontrol $=0$ menit perendaman; 30 menit $=30$ menit perendaman dalam ekstrak; 60 menit $=60$ menit perendaman dalam ekstrak; 90 menit= 90 menit perendaman dalam ekstrak

Gambar 2. Pertumbuhan mikroorganisme pada bakso dengan perendaman ekstrak kulit jeruk selama masa penyimpanan
Minyak atsiri dapat menghambat pertumbuhan atau mematikan bakteri dengan mengganggu proses terbentuknya membran dan dinding sel yang tidak terbentuk sempurna (Mehmood et al., 2015). Terpenoid juga dilaporkan melimpah pada ekstrak kulit jeruk manis menggunakan etanol dengan mekanisme merusak membran lipofilik bakteri (Shetty et al., 2016).

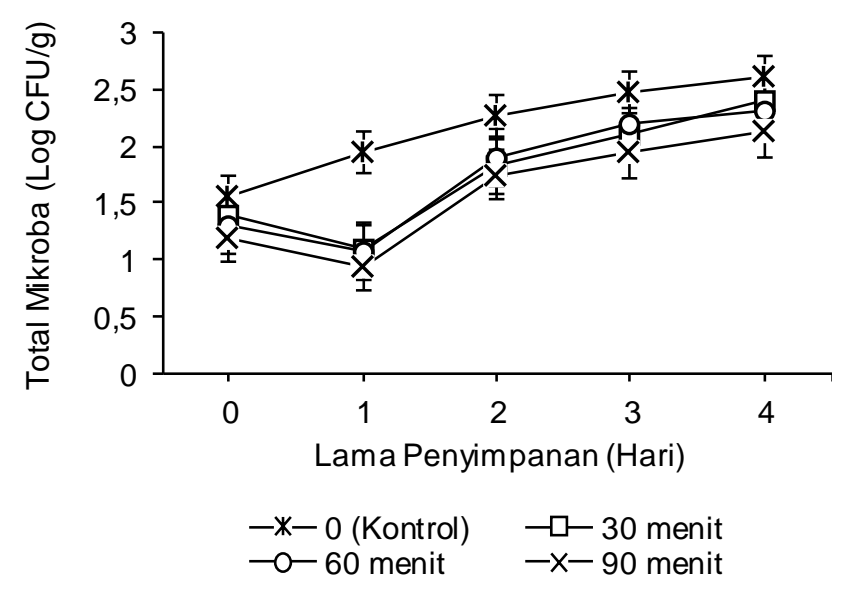

Keterangan: Kontrol $=0$ menit perendaman; 30 menit $=30$ menit perendaman dalam ekstrak; 60 menit $=60$ menit perendaman dalam ekstrak; 90 menit $=90$ menit perendaman dalam ekstrak

Gambar 3. Pertumbuhan mikroorganisme pada mi dengan perendaman ekstrak kulit jeruk selama masa penyimpanan

Pada Gambar 4, perendaman selama 90 menit memberikan hasil terbaik dengan total mikroba terkecil produk pangan tahu hingga hari ke-4 dibandingkan dengan tahu kontrol. Perbedaan bahan pangan antara tahu dan bakso daging memiliki penghambatan yang berbeda oleh ekstrak kulit jeruk dikarenakan kandungan bahan dari kedua produk berbeda. Kandungan bahan dinilai sebagai substrat yang dibutuhkan untuk mendukung pertumbuhan mikroorganisme, makin kompleks unsur $\mathrm{C}, \mathrm{H}, \mathrm{N}$, dan berbagai vitamin serta mineral maka semakin cepat total mikrorganisme dalam bahan yang harus dihambat oleh ekstrak jeruk manis. Ekstrak jeruk manis yang mengandung senyawa antibakteri 1,8-cineole (Mayaud et al., 2008), d-limonene (Favela-Hernández et al., 2016), dan senyawa 5-C-glycosyl flavones: lucenin-2, vicenin-2, stellarin-2, lucenin-2-41methyl ether and scoparin; one 3-hydroxy-3-methylglutaryl glycolsyl flavonol: 3-hydroxy-3-methyl-glutaryl glycosyl quercetin (Barecca et al., 2014) yang dapat menghambat mikroorganisme, sehingga menambah umur simpan dari bahan pangan setelah direndam ekstrak. 


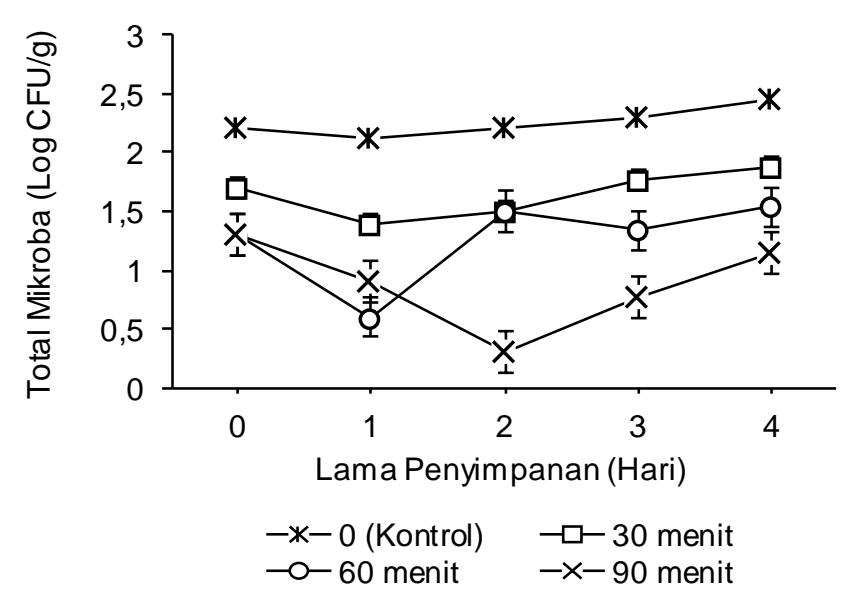

Keterangan : Kontrol $=0$ menit perendaman; 30 menit $=$ 30 menit perendaman dalam ekstrak; 60 menit $=60$ menit perendaman dalam ekstrak; 90 menit $=90$ menit perendaman dalam ekstrak

Gambar 4. Pertumbuhan mikroorganisme pada tahu dengan perendaman ekstrak kulit jerukselama masa penyimpanan

\section{Pengamatan visual pada bahan pangan}

Pengamatan pada bakso yang ditunjukkan pada Tabel 4, menunjukkan bahwa hingga hari ke-4 aroma tidak menunjukkan kerusakan. Hal ini dikarenakan senyawa kimia yang terkandung dalam ekstrak kulit jeruk manis memiliki konsentrasi yang tinggi dimana dapat melarutkan beberapa komponen bahan seperti karbohidrat dan protein. Penurunan $\mathrm{pH}$ pada ekstrak kulit jeruk juga membuat destabilisasi dari protein daging sehingga memengaruhi protein struktur dan membuat daging menjadi lembek setelah hari ke-3 dengan pengamatan yang dilakukan setiap hari. Menurut Sugiyono (1996), pelunakan pada bakso daging disebabkan keadaan postrigor pada daging karena proses pembongkaran jaringan pengikat oleh enzim proteolitik yang dihasilkan secara alami oleh otot dan mikroorganisme yang tumbuh kembali setelah hari ke-2 yang ditunjukkan pada gambar 2. Hal tersebut mengakibatkan pelunakan pada jaringan daging pada bahan makanan bakso.
Fenomena yang sama juga ditunjukkan dari mi dan tahu pada Tabel 5 dan 6 , aroma dan warna mi masih belum rusak hingga hari ke-4 setelah perendaman ekstrak. Hal ini dikarenakan konsentrasi sebesar $500 \mathrm{mg} / \mathrm{ml}$ ekstrak yang dicampurkan ternyata akan cepat menguap dan bersifat inert pada aroma dan warna dari bahan makanan mi. Aroma mi dipengaruhi oleh komponen bahan penyusun mi seperti protein yang terdenaturasi akibat proses pembuatan mi menghasilkan asam amino yang berperan dalam menyusun aroma pada mi basah. Warna kuning mi dihasilkan dari proses pemasakan. Tekstur dari mi basah juga mengalami penurunanpada hari ke-4 dikarenakan terlarutnya protein gluten penyusun mi basah akibat makin lamanya perendaman.

Tabel 6 menunjukkan tekstur tahu juga dinyatakan rusak oleh panelis pada penyimpanan hingga hari ke-4 setelah direndam ekstrak selama 30, 60, dan 90 menit. Pada prose pembuatan tahu, menggunakan prinsip salting out protein kedelai dimana protein kedelai telah mengalami destabilisasi akibat penurunan $\mathrm{pH}$. Setelah direndam dengan ekstrak kulit jeruk manis, tekstur pada tahu akan makin melunak dan lembek dikarenakan struktur protein yang membentuk tekstur makin lemah ikatannya dengan lamanya penyimpanan pada suhu ruang hingga hari ke-4.

Pelunakan tekstur juga terjadi karena aktivitas mikroorganisme yang memproduksi enzim proteolitik ditambah dengan makin menurunnya $\mathrm{pH}$ selama penyimpanan. Parameter warna dan aroma pada hari ke-4 sudah dikarenakan aroma yang terben-tuk sudah menyimpang akibat degradasi protein tahu menjadi asam-asam amino dan protein rantai pendek yang volatil dan beraroma menyimpang. Paramater warna produk tahu juga menunjukkan penolakan/dinyatakan rusak oleh panelis pada hari ke4 penyimpanan suhu ruang. Warna pada tahu cenderung kecoklatan dikarenakan aktivitas mikroorganisme yang kembali naik pada hari ke-4 setelah perendaman. Mikroorganisme memanfaatkan substrat pati dan protein yang sudah sederhana dan membentuk koloni sehingga dapat diketahui warna dari tahu pada hari ke-4 sudah menyimpang.

Tabel 4. Penampakan warna, aroma, dan tekstur bakso selama penyimpanan suhu ruang

\begin{tabular}{|c|c|c|c|c|c|c|c|c|c|c|c|c|}
\hline \multirow{3}{*}{$\begin{array}{l}\text { Hari } \\
\text { ke- }\end{array}$} & \multicolumn{12}{|c|}{ Parameter } \\
\hline & \multicolumn{4}{|c|}{ Warna } & \multicolumn{4}{|c|}{ Aroma } & \multicolumn{4}{|c|}{ Tekstur } \\
\hline & Kontrol & $30^{\prime}$ & $60^{\prime}$ & $90^{\prime}$ & Kontrol & $30^{\prime}$ & $60^{\prime}$ & $90^{\prime}$ & Kontrol & $30^{\prime}$ & $60^{\prime}$ & $90^{\prime}$ \\
\hline 0 & - & - & - & - & - & - & - & - & - & - & - & - \\
\hline 1 & + & + & + & + & + & + & + & + & + & + & + & + \\
\hline 2 & + & + & + & + & + & + & + & + & ++ & ++ & ++ & ++ \\
\hline 3 & + & + & + & + & + & + & + & + & +++ & +++ & +++ & +++ \\
\hline 4 & + & ++ & ++ & ++ & + & + & + & + & ++++ & ++++ & ++++ & ++++ \\
\hline
\end{tabular}

Keterangan: $(-)$ = Normal; $(+)$ = Sedikit rusak; $(++)$ = Agak rusak; $(+++)$ = Rusak; $(++++)$ = Sangat rusak 
Tabel 5. Penampakan warna, aroma, dan tekstur mi selama penyimpanan suhu ruang

\begin{tabular}{cccccccccccccc}
\hline \multirow{2}{*}{$\begin{array}{c}\text { Hari } \\
\text { ke- }\end{array}$} & \multicolumn{10}{c}{ Warna } & \multicolumn{10}{c}{ Aroma } \\
\cline { 2 - 13 } & Kontrol & $30^{\prime}$ & $60^{\prime}$ & $90^{\prime}$ & Kontrol & $30^{\prime}$ & $60^{\prime}$ & $90^{\prime}$ & Kontrol & $30^{\prime}$ & $60^{\prime}$ & $90^{\prime}$ \\
\hline 0 & - & - & - & - & - & + & - & - & - & - & - & - & - \\
1 & - & + & + & + & + & + & + & + & + & + & + & + \\
2 & - & + & + & + & + & + & + & + & ++ & ++ & ++ & ++ & ++ \\
3 & - & + & + & + & + & + & + & + & +++ & +++ & +++ & +++ \\
4 & - & + & + & + & + & + & + & + & ++++ & ++++ & ++++ & ++++ \\
\hline
\end{tabular}

Keterangan: $(-)=$ Normal; $(+)=$ Sedikit rusak; $(++)=$ Agak rusak; $(+++)=$ Rusak; $(++++)$ = Sangat rusak

Tabel 6. Penampakan warna, aroma, dan tekstur tahu selama penyimpanan suhu ruang

\begin{tabular}{|c|c|c|c|c|c|c|c|c|c|c|c|c|}
\hline \multirow{3}{*}{$\begin{array}{l}\text { Hari } \\
\text { ke- }\end{array}$} & \multicolumn{12}{|c|}{ Parameter } \\
\hline & \multicolumn{4}{|c|}{ Warna } & \multicolumn{4}{|c|}{ Aroma } & \multicolumn{4}{|c|}{ Tekstur } \\
\hline & Kontrol & $30^{\prime}$ & $60 '$ & $90^{\prime}$ & Kontrol & $30^{\prime}$ & $60^{\prime}$ & $90^{\prime}$ & Kontrol & 30 & $60^{\prime}$ & $90^{\prime}$ \\
\hline 0 & - & - & - & - & - & - & - & - & - & - & - & - \\
\hline 1 & - & + & + & + & + & + & + & + & + & + & + & + \\
\hline 2 & + & + & + & + & ++ & + & + & + & ++ & ++ & ++ & ++ \\
\hline 3 & + & + & + & + & ++ & + & + & + & +++ & +++ & +++ & +++ \\
\hline 4 & ++ & ++ & ++ & ++ & +++ & + & + & + & ++++ & ++++ & ++++ & ++++ \\
\hline
\end{tabular}

Keterangan: $(-)=$ Normal; $(+)=$ Sedikit rusak; $(++)=$ Agak rusak; $(+++)=$ Rusak; $(++++)$ = Sangat rusak

\section{KESIMPULAN}

Pembuatan pengawet alami dari kulit jeruk manis (Citrus senensis) yang diekstraksi dengan metode maserasi menggunakan etanol memiliki aktivitas antibakteri dengan diameter zona hambat sebesar $17,67 \pm 0,58 \mathrm{~mm}$ terhadap Escherichia coli, 16, \pm 1

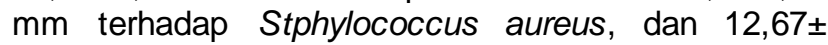
$1,15 \mathrm{~mm}$ penghambatan terhadap bakteri SalmoneIla tphyii. Ekstrak kulit jeruk manis memiliki aktivitas antioksidan sebesar $66,41 \%$ dengan total fenol $2.656,48 \pm 55,46 \mathrm{mg}$ GAE $/ 100 \mathrm{~g}$. Pengujian terhadap bahan makanan (bakso, mi basah, dan tahu) dengan lama perendaman 90 menit dapat menekan total bakteri selama 4 hari dengan kerusakan warna, aroma, dan tekstur hingga hari ke-4 selama penyimpanan pada suhu ruang.

\section{DAFTAR PUSTAKA}

Agbor GA, Vinson JA, Donnelly PE. 2014. Folinciocalteau reagent for polyphenolic assay. Int $\mathrm{J}$ Food Sci Nutr Diet 3: 147-156. DOI: 10.19070/ 2326-3350-1400028.

Arisanti RR, Indriani C, Wilopo SA. 2018. Kontribusi agen dan faktor penyebab kejadian luar biasa keracunan pangan di Indonesia: Kajian sistematis. Berita Kedokteran Masyarakat 34: 99106. DOI: $10.22146 / \mathrm{bkm} .33852$.

[BPOM] Badan Pengawas Obat dan Makanan. 2013. Peraturan Menteri Kesehatan Republik Indonesia Nomor 2 Tahun 2013 Tentang Kejadian Luar Biasa Keracunan Pangan. Jakarta.
Barreca D, Bellocco E, Leuzzi U, Gattuso G. 2014. First evidence of $\mathrm{C}$ - and $\mathrm{O}$ glycosyl flavone in blood orange (Citrus senensis (L.) Osbeck) juice and their influence on antioxidant properties. Food Chem 149: 244-252. DOI: 10.1016/j. foodchem.2013.10.096.

Boudhrioua N, loannou, Paris C, Ghoul M. 2016. Comparison of the efficiency of different extraction methods on antioxidants of maltease orange peel. Int J Food Nutr Sci 3: 239-251. DOI: $10.15436 / 2377-0619.16 .789$

Chalova VI, Crandall PG, Ricke SC. 2012. Microbial inhibitory and radical scavenging activities of cold-pressed terpeneless Valencia orange (Citrus sinensis) oil in different dispersing agents. J Sci Food Agric 90: 870-876. DOI: 10.1002/jsfa. 3897.

Jorge N, da Sillva AC, Aranha CPM. 2016. Antioxidant activity of oils extracted from orange (Citrus senensis) seeds. Ann Acad Bras Cienc 88: 951-958. DOI: $10.1590 / 0001-3765201620140$ 562.

Kaviya S, Santhanalakshmi J, Viswanathan B, Muthumary J, Srinivasan K. 2011. Biosynthesis of silver nanoparticles using Citrus sinensis peel extract and its antibacterial activity. Spectrochim Acta A 79: 594-598. DOI: 10.1016/j.saa.20 11.03.040.

Kementrian Pertanian RI. 2010. Tanaman Jeruk Bali di Indonesia. Ayunda 1(7): 36-43

Liu K, Chen Q, Liu Y, Zhou X, Wang X. 2012. Isolation and biological activities of decanal, linalool, valencene, and octanal from sweet orange oil. $J$ Food Sci 77: 1156-1161. DOI: 10.1111/j.17503841.2012.02924.x. 
Favela-Hernández JMJ, González-Santiago O, Ramírez-Cabrera MA, Esquivel-Ferriño PC, Camacho-Corona MR. 2016. Review: Chemistry and pharmacology of Citrus sinensis. Molucules 21: 247. DOI: 10.3390/molecules21020247.

Mayaud L, Carricajo A, Zhiri A, Aubert G. 2008. Comparison of bacteriostatic and bactericidal activity of 13 essential oils against strains with varying sensitivity to antibiotics. Lett Appl Microbiol 47: 167-173. DOI: 10.1111/j.1472-765 X.2008.02406.x.

Mehmood B, Dar KK, Ali S, Awan UA, Nayyer AQ, Ghous T, Andleeb S. 2015. Short Communication: In vitro assessment of antioxidant, antibacterial and phytochemical analysis of peel of Citrus sinensis. Pak J Pharm Sci 28: 231-239.

Mulyono LM. 2013. Aktivitas antibakteri ekstrak etanol biji buah pepaya (Carica papaya L.) terhadap Escherichia coli dan Staphylococcus aureus. J Ilmiah Mahasiswa Universitas Surabaya $2: 1-9$.

O'Bryan CA, Crandall PG, Chalova VI, Ricke SC. 2008. Orange essential oils antimicrobial activities against Salmonella spp. J Food Sci 73: 264-267. DOI: 10.1111/j.1750-3841.2008.0079 $0 . x$.

Pandey A, Kaushik A, Tiwari SK. 2011. Evaluation of antimicrobial activity and phytochemical analysis of Citrus limon. J Pharm Biomed Sci 13: 15.
Prakash A, Rigelhof F, Miller E. 2010. Antioxidant Activity. http://www.medallionlabs.com [27 Januari 2017].

Rafsanjani MK, Putri WDR. 2015. Karakterisasi ekstrak kulit jeruk bali menggunakan metode ultrasonic Bath (Kajian pernedaan pelarut dan lama ekstraksi). J Pangan Agroind 3: 1473-1480

Shetty SB, Mahin-Syed-Ismail $P$, Varghese S, Thomas-Geogre B, Kandathil-Thajurat P, Baby D, Haleem S, Sreedhar S, Devang D. 2016. Antimicrobial effects of Citrus sinensis peel extracts against dental caries bacteria: An in vitro study. J Clin Exp Dent 8: 71-77. DOI: 10.4317/ jced.52493.

Sugiyono. 1996. Pengetahuan Bahan. 3-37. Buku Ajar IKIP Fakultas Teknologi dan Kejuruan, Yogyakarta.

Suryanti A, Wulandari M, Rahayu A. 2011. Pengaruh dosis dan lama perendaman larutan lengkuas terhadap jumlah bakteri ikan bandeng. J Ilmu Pendidikan Yogyakarta 7: 1-9.

Satyajaya W, Nawasih O. 2008. Pengaruh konsentrasi chitosan sebagai bahan pengawet terhadap masa simpan mi basah. J Teknol Industri Hasil Pertanian 13: 17-24.

Tohyeng N, Dewanti-Hariyadi R, Lioe HN. 2018. Aplikasi ekstrak kunyit untuk pengendalian mikroba pada tahu selama penyimpanan. J Teknol Industri Pangan 29: 19-28. DOI: 10.6066/jtip.20 18.29.1.19. 